\title{
TETRAHYDROSWERTIANOLIN: A POTENT HEPATOPROTECTIVE AGENT FROM SWERTIA JAPONICA MAKINO
}

Koji HASE, ${ }^{\mathrm{a}}$ Shigetoshi KADOTA, ${ }^{*}$ a Purusotam BASNET, $^{\mathrm{a}}$ Jianxin LI, ${ }^{\mathrm{a}}$ Shuichi TAKAMURA, ${ }^{\mathrm{b}}$ and Tsuneo NAMBA $^{\mathrm{a}}$

Research Institute for Wakan-Yaku (Traditional Sino-Japanese Medicines), ${ }^{a}$ Toyama Medical and Pharmaceutical University, 2630-Sugitani, Toyama 930-01, Japan and Health Science Laboratories, ${ }^{b}$ Yamanouchi Pharmaceutical Co., Ltd., 2-3-11, Nihonbashi-Honcho, Chuo-ku, Tokyo 103, Japan

Tetrahydroswertianolin (1), a new tetrahydroxanthone glycoside, was isolated from the whole plant of Swertia japonica MAKINO (Gentianaceae). Its structure was determined by chemical and spectroscopic methods including 2D-NMR. This compound was found to be very effective in immunologically induced liver injury in mice.

KEY WORDS Swertia japonica; Gentianaceae; tetrahydroswertianolin; tetrahydroxanthone; D-galactosamine/lipopolysaccharide-induced liver injury

Swertiae Herba, the whole plant of Swertia spp., has been widely used in Ayurvedic and Unani medicines as an anthelminthic, febrifuge, and liver tonic. In Japan, Swertia japonica MAKINO is a popular medicinal herb for stomach complaints. In serial research on hepatoprotective agents from natural sources, ${ }^{1)}$ S. japonica showed a significant hepatoprotective activity, and activity-guided fractionation yielded a new tetrahydroxanthone from this plant. This communication deals with the structure elucidation of tetrahydroswertianolin, a saturated analogue of swertianolin, and its hepatoprotective activity against immunological liver injury.

The shade-dried whole plant $(5 \mathrm{~kg}$ ) was extracted with $70 \%$ aqueous ethanol to obtain aqueous ethanolic extract $(1330 \mathrm{~g})$. This extract was partitioned into EtOAc $(455.5 \mathrm{~g})-, n-\mathrm{BuOH}(438.7 \mathrm{~g})$-, and aqueous $(495.0 \mathrm{~g})$-soluble fractions, respectively. Among the three fractions, the $n$ - $\mathrm{BuOH}$-soluble fraction showed strong protective activity against D-galactosamine (D-GalN)/lipopolysaccharide (LPS)-induced liver injury. Therefore, a part $(80 \mathrm{~g})$ of this fraction was subjected to Sephadex LH-20 column chromatography and eluted with 30-80\% $\mathrm{MeOH}$ in water to give eight fractions. Since the $30 \% \mathrm{MeOH}$ eluate $(5.5 \mathrm{~g}$ ) exhibited the strongest activity of all fractions, it was further purified by silica gel column chromatography. Thus activity-guided fractionation finally gave tetrahydroswertianolin (1) $(950 \mathrm{mg})$. The structure of 1 was determined by chemical and spectroscopic methods.

Tetrahydroswertianolin $(\mathbf{1})$, a yellow amorphous solid, showed $[\alpha]_{\mathrm{D}}{ }^{20}+8.0^{\circ}(\mathrm{MeOH}, c=0.2)$. The positive ion FAB-mass of 1 exhibited a quasi-molecular ion peak at $\mathrm{m} / \mathrm{z} 441$, and its molecular formula was determined to be $\mathrm{C}_{20} \mathrm{H}_{24} \mathrm{O}_{11}\left\{\mathrm{~m} / z: 441.1389[\mathrm{M}+\mathrm{H}]^{+}\right.$, calcd 441.1397$\}$ by high-resolution FAB-MS. Its IR spectrum showed a sharp peak at $\lambda_{\max } 1660 \mathrm{~cm}^{-1}(\mathrm{CO})$. The ${ }^{1} \mathrm{H}-\mathrm{NMR}$ data ${ }^{2)}$ coupled with detailed analysis of ${ }^{1} \mathrm{H}-{ }^{1} \mathrm{H}$ COSY indicated the presence of 19 proton signals: meta-coupled aromatic protons at $\delta_{\mathrm{H}} 6.29$ and 6.59 (each $1 \mathrm{H}, \mathrm{d}, J=2.0 \mathrm{~Hz}$ ), methylene protons at $\delta_{\mathrm{H}} 2.11(2 \mathrm{H}, \mathrm{m})$ coupling with other methylene protons at $\delta_{\mathrm{H}} 1.79(1 \mathrm{H}, \mathrm{br} \mathrm{tt}, J=13.5,3.0 \mathrm{~Hz})$ and 2.30<smiles>COc1cc(O)c2c(=O)c3c(oc2c1)[C@H](O)CC[C@H]3O</smiles>

$1: \mathrm{R}=\beta$-D-glucopyranosyl $1 \mathrm{a}: \mathrm{R}=\mathrm{H}$<smiles>COc1cc(O)c2c(=O)c3c(O)ccc(O)c3oc2c1</smiles>

$2: \mathrm{R}=\beta$-D-glucopyranosyl $3: R=H$<smiles>COc1cc(O)c2c(=O)c3ccccc3oc2c1</smiles>

4 


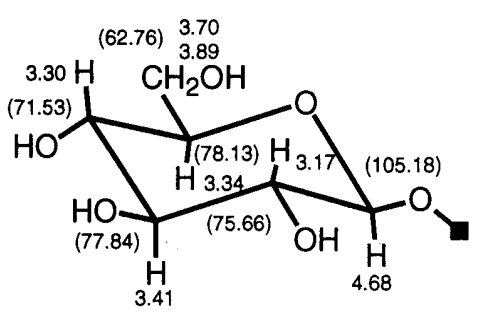

[ I ]

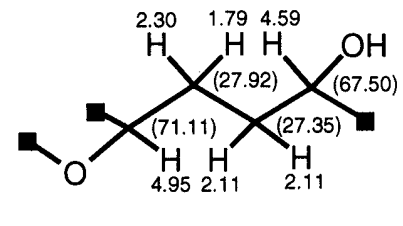

[II]

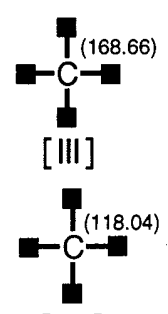

[IV]

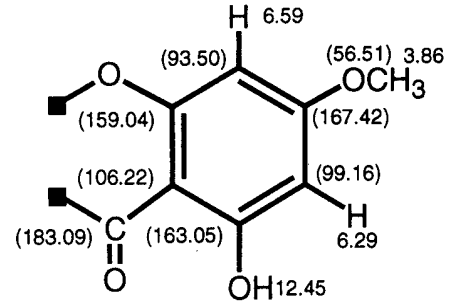

[V]

Fig. 1. Partial Structures Observed by ${ }^{1} \mathrm{H}$ and ${ }^{13} \mathrm{C}-\mathrm{NMR},{ }^{1} \mathrm{H}-{ }^{1} \mathrm{H}$ COSY, and ${ }^{1} \mathrm{H}^{-13} \mathrm{C}$ COSY Spectra of 1

$(1 \mathrm{H}, \mathrm{dq}, J=13.5,3.0 \mathrm{~Hz})$, two oxygen-bearing methine protons at $\delta_{\mathrm{H}} 4.59(1 \mathrm{H}, \mathrm{dd}, J=9.5,7.0 \mathrm{~Hz})$ and $4.95(1 \mathrm{H}, \mathrm{t}$, $J=3.0 \mathrm{~Hz}$ ), and seven protons due to the sugar part. In addition, methoxy protons at $\delta_{\mathrm{H}} 3.86(3 \mathrm{H}, \mathrm{s})$ and a hydroxy proton at $\delta_{\mathrm{H}} 12.45(1 \mathrm{H}, \mathrm{s})$ were observed. The ${ }^{13} \mathrm{C}-\mathrm{NMR}$ and DEPT spectra ${ }^{2)}$ showed 20 carbon signals: eight carbon signals were similar to those of the partial structure of swertianolin (2) and its aglycone, bellidifolin $(3),{ }^{3)}$ except for two quaternary carbons $\left(\delta_{\mathrm{c}} 118.04,168.66\right)$, two methylene carbons $\left(\delta_{\mathrm{c}} 27.35,27.92\right)$, and two methine carbons bonded to oxygen $\left(\delta_{\mathrm{c}} 67.50,71.11\right)$.

Treatment of 1 with $\beta$-glucosidase gave $1 \mathrm{a}$ and glucose. Acid hydrolysis of 1 with $5 \% \mathrm{HCl}, 1$-hydroxy-3methoxyxanthone (4) was mainly obtained instead of 1a, together with glucose.

These data and detailed ${ }^{1} \mathrm{H}$ - and ${ }^{13} \mathrm{C}-\mathrm{NMR}$ studies of 1 with the aid of ${ }^{1} \mathrm{H}-{ }^{1} \mathrm{H}$ and ${ }^{1} \mathrm{H}-{ }^{13} \mathrm{C}$ COSY led us to conclude that 1 may be a tetrahydroxanthone with partial structures [I, II, III, IV, and V] as shown in Fig. 1.

The linkage of partial structures was confirmed by $a^{1} \mathrm{H}^{13} \mathrm{C}$ long-range COSY experiment. The anomeric carbon at $\delta_{\mathrm{C}} 105.18$ in the sugar moiety showed a cross peak with the methine proton at $\delta_{\mathrm{H}} 4.95$ in structure [II]. Furthermore, this proton showed cross peaks with the carbonyl carbon at $\delta_{\mathrm{C}} 183.09$ in structure [V], and two quaternary carbons at $\delta_{\mathrm{C}} 168.66$ and 118.04 in structures [III] and [IV]. Also, some of the significant ${ }^{1} \mathrm{H}-{ }^{13} \mathrm{C}$ long-range correlations are indicated by arrows in the formula in Fig. 2-A. Thus the planar structure of this compound was shown to be 1 .

The relative configuration of 1 was determined by an NOE experiment. On irradiation of the $7-\mathrm{H}_{\mathrm{ax}}$ proton $\left(\delta_{\mathrm{H}}\right.$ 1.79), an NOE was observed at $5-\mathrm{H}\left(\delta_{\mathrm{H}} 4.59\right)$ and $8-\mathrm{H}\left(\delta_{\mathrm{H}} 4.95\right)$, while in contrast, on irradiation of the $7-\mathrm{H}_{\mathrm{eq}}\left(\delta_{\mathrm{H}}\right.$ 2.30), no NOE was observed (Fig 2-B). These NOE data suggest that 5-H and 8-H were in cis configuration, which was further supported by the $J$-value of ${ }^{1} \mathrm{H}-\mathrm{NMR}$. The coupling constant between $7-\mathrm{H}$ and $8-\mathrm{H}$ was small $(J=3.0 \mathrm{~Hz})$ and thus $8-\mathrm{H}$ is quasi-equatorial and the $8-O$-glucosyl moiety is quasi-axial. On the other hand, $5-\mathrm{H}$ is quasi-axial because it has a large coupling constant (dd, $J=9.5,7.3 \mathrm{~Hz}$ ). Thus, Dreiding model analysis together with the analysis of the $J$-value from ${ }^{1} \mathrm{H}$-NMR and NOE experiments suggest that the tetrahydrobenzene ring in $\mathbf{1}$ might be in distorted half-chair conformation with equatorial 5-OH and axial 8-O-glucose.
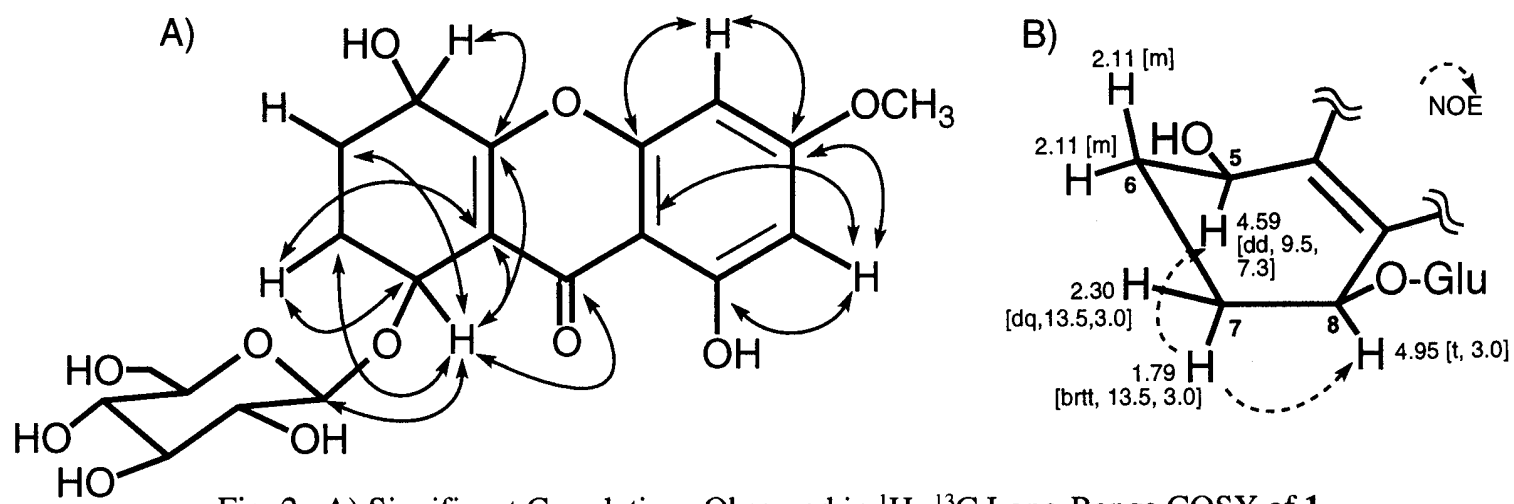

Fig. 2. A) Significant Correlations Observed in ${ }^{1} \mathrm{H}-{ }^{13} \mathrm{C}$ Long-Range COSY of 1

B) Relative Configuration Proposed for Tetrahydrobenzene Ring of 1 
Mosher's method ${ }^{4)}$ applied to $\alpha$-methoxy- $\alpha$-trifluoromethylphenylacetyl (MTPA) esters of 1 led to the confirmation of the $(R)$-configuration of the 5-position, since the chemical shift due to the 5-H signal of the $(S)$ MTPA ester was shifted upfield by $0.18 \mathrm{ppm}$ compared with that of the $(R)$-MTPA ester, and that of the 6-Ha and 6$\mathrm{Hb}$ signals of the (S)-MTPA ester was shifted downfield by 0.03 and $0.09 \mathrm{ppm}$ compared with that of the $(R)$-MTPA ester. Based on these spectral data, the absolute configuration of tetrahydroswertianolin was determined as represented by formula 1.

There are very few partially saturated xanthones as natural products, and this is the first report to find such a compound in Swertia spp. We investigated its hepatoprotective activity against immunologically induced liver injury. Co-administration of D-GalN (700 mg/kg) and LPS $(10 \mu \mathrm{g} / \mathrm{kg})$ is known to induce liver injury through the immune response in mice. ${ }^{5)}$ The extent of liver damage was expressed in terms of the alanine aminotransferase (ALT) level. In the normal group, the blood ALT level was $44.5 \pm 2.3$ (mean $\pm \mathrm{SE}$ ) U/l, whereas in the control group, it was elevated to $2843 \pm 702 \mathrm{U} / 18 \mathrm{~h}$ after D-GalN/LPS challenge. When 1 ( 25 or $50 \mathrm{mg} / \mathrm{kg}$, s.c.) was administered 18 and $2 \mathrm{~h}$ before D-GalN/LPS challenge, the blood ALT level was $942 \pm 296$ ( $p<0.05$ vs. control) or $490 \pm 121 \mathrm{U} / \mathrm{l}(p<0.05)$, respectively. On the other hand, in the glycyrrhizin $(100 \mathrm{mg} / \mathrm{kg}$, s.c.)-treated group, it was $1121 \pm 453 \mathrm{U} / \mathrm{l}(p<0.05)$. These data clearly suggest that 1 showed a significant and dose-dependent hepatoprotective effect in this D-GalN/LPSinduced liver injury model. Its effect was stronger than that of glycyrrhizin as a positive control. Furthermore, the hepatoprotective activity of aglycone (1a) and its derivative (4) also investigated. In controls, the ALT level was 1989 $\pm 689 \mathrm{U} / \mathrm{l}$, whereas in the $1 \mathrm{a}(25 \mathrm{mg} / \mathrm{kg}$, s.c.)-treated group, it was significantly suppressed to $477 \pm 98 \mathrm{U} / \mathrm{l}(p<0.05)$. In contrast, $4(25 \mathrm{mg} / \mathrm{kg}$, s.c.) treatment did not show any activity $(1865 \pm 624 \mathrm{U} / \mathrm{l})$. The results clearly suggest that the tetrahydrobenzene-ring structure is essential for the hepatoprotective activity of tetrahydroswertianolin (1). Further studies on the hepatoprotective mechanism are in progress in our laboratory.

\section{REFERENCES AND NOTES}

1) Hase K., Kadota S., Basnet P., Namba T., Takahashi T., Phytotherapy Res., 10, 387-392 (1996); Hase K., Kadota S., Basnet P., Namba T., Biol. Pharm. Bull., 19, 567-572 (1996).

2) Tetrahydroswertianolin (1): a yellow amorphous solid; $[\alpha]_{\mathrm{D}}^{20}+8.0^{\circ}(\mathrm{MeOH}, c=0.2)$; UV $\lambda \max \mathrm{nm}(\log \varepsilon): 210$ (3.93), 233 (4.03), 252 (4.19), 258 (4.18), 293 (3.77), 325 (3.51); IR $v_{\max }(\mathrm{KBr}) \mathrm{cm}^{-1}: 3380,2890,1660,1450$, 1070; ${ }^{1} \mathrm{H}-\mathrm{NMR}\left(\mathrm{CD}_{3} \mathrm{OD}\right) \delta: 1.79(1 \mathrm{H}, \mathrm{br} \mathrm{tt}, J=13.5,3.0 \mathrm{~Hz}, 7-\mathrm{Hax}), 2.11(2 \mathrm{H}, \mathrm{m}, 6-\mathrm{H}), 2.30(1 \mathrm{H}, \mathrm{dq}, J=$ 13.5, $3.0 \mathrm{~Hz}, 7-\mathrm{Heq}), 3.17\left(1 \mathrm{H}, \mathrm{dd}, J=9.0,8.0 \mathrm{~Hz}, 2^{\prime}-\mathrm{H}\right), 3.30\left(1 \mathrm{H}, \mathrm{m}, 4^{\prime}-\mathrm{H}\right), 3.34\left(1 \mathrm{H}, \mathrm{m}, 5^{\prime}-\mathrm{H}\right), 3.41(1 \mathrm{H}, \mathrm{t}, J$ $\left.=9.0 \mathrm{~Hz}, 3^{\prime}-\mathrm{H}\right), 3.70\left(1 \mathrm{H}, \mathrm{dd}, J=12.0,5.0 \mathrm{~Hz}, 6^{\prime}-\mathrm{Ha}\right), 3.86\left(3 \mathrm{H}, \mathrm{s}, 3-\mathrm{OCH}_{3}\right), 3.89\left(1 \mathrm{H}, \mathrm{dd}, J=12.0,2.0 \mathrm{~Hz}, 6^{\prime}-\right.$ $\mathrm{Hb}), 4.59(1 \mathrm{H}, \mathrm{dd}, J=9.5,7.0 \mathrm{~Hz}, 5-\mathrm{H}), 4.68\left(1 \mathrm{H}, \mathrm{d}, J=8.0 \mathrm{~Hz}, 1^{\prime}-\mathrm{H}\right), 4.95(1 \mathrm{H}, \mathrm{t}, J=3.0 \mathrm{~Hz}, 8-\mathrm{H}), 6.29(1 \mathrm{H}$, $\mathrm{d}, J=2.0 \mathrm{~Hz}, 2-\mathrm{H}), 6.59(1 \mathrm{H}, \mathrm{d}, J=2.0 \mathrm{~Hz}, 4-\mathrm{H}), 12.45(1 \mathrm{H}, \mathrm{s}, 1-\mathrm{OH}) ;{ }^{13} \mathrm{C}-\mathrm{NMR}\left(\mathrm{CD}_{3} \mathrm{OD}\right) \delta: 27.35(\mathrm{t}, 6-\mathrm{C})$, 27.92 (t, 7-C), $56.51\left(\mathrm{q}, 3-\mathrm{OCH}_{3}\right), 62.76\left(\mathrm{t}, 6^{\prime}-\mathrm{C}\right), 67.50$ (d, 5-C), 71.11 (d, 8-C), 71.53 (d, 4'-C), 75.66 (d, 2'C), 77.84 (d, 3'-C), 78.13 (d, 5'-C), 93.50 (d, 4-C), 99.16 (d, 2-C), 105.18 (d, 1'-C), 106.22 (s, 9a-C), 118.04 (s, 8a-C), 159.04 (s, 4a-C), 163.05 (s, 1-C), 167.42 (s, 3-C), 168.66 (s, 4b-C), 183.09 (s, 9-C). Assignment of ${ }^{1} \mathrm{H}-$ and ${ }^{13} \mathrm{C}-\mathrm{NMR}$ signals were confirmed by ${ }^{1} \mathrm{H}-{ }^{1} \mathrm{H},{ }^{1} \mathrm{H}-{ }^{13} \mathrm{C}$, and ${ }^{1} \mathrm{H}-{ }^{13} \mathrm{C}$ long-range COSY.

3) Basnet P., Kadota S., Shimizu M., Namba T., Planta Med., 60, 507-511 (1994); Tomimori T., Yoshizaki M., Namba T., Yakugaku Zasshi, 94, 647-651 (1974); Sakamoto I., Tanaka T., Tanaka O., Tomimori T., Chem. Pharm. Bull., 30, 4088-4091 (1982).

4) Dale J. A., Mosher H. S., J. Am. Chem. Soc. 95, 512-519 (1973).

5) Tiegs G., Wolter M., Wendel A., Biochem. Pharmacol., 38, 627-631 (1989); Freudenberg M.A., Galanos C., Infect. Immun., 59, 2110-2115 (1991); Hishinuma I., Nagakawa J., Hirota K., Miyamoto K., Tsukidate K., Yamanaka T., Katayama K., Yamatsu I., Hepatology, 12, 1187-1191 (1990). 